\title{
"Starfish" hand
}

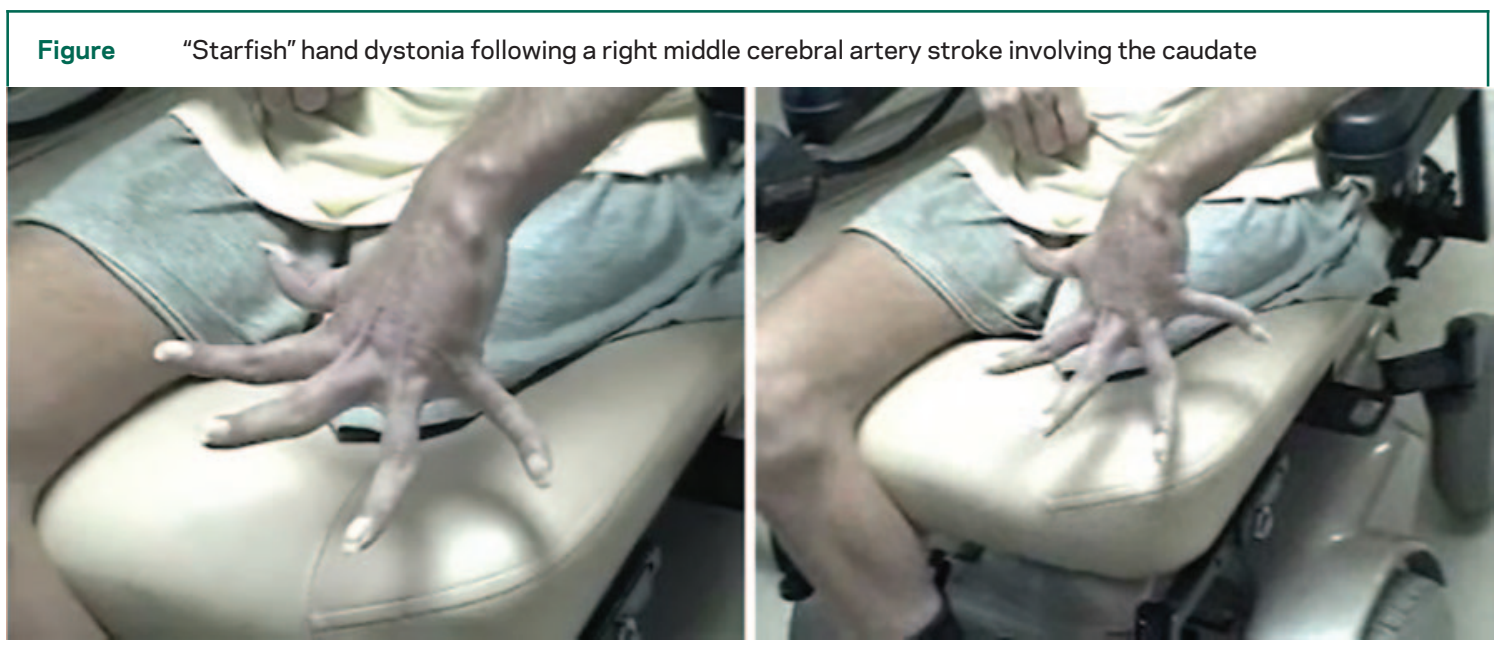

VIDEO A 57-year-old man with known right carotid occlusion had a right middle cerebral artery stroke involving

Supplemental data at www.neurology.org the caudate head, perisylvian, and temporal-parietal-occipital watershed regions. This caused left arm weakness and gradually severe dystonia emerged in his left hand with spreading of his fingers in a "starfish" pattern (figure, video [www.neurology.org]). One series of botulinum toxin injections was moderately effective. In one study of 1,500 consecutive patients with stroke, 16 developed dystonia. ${ }^{1}$ Infarcts in the caudate, putamen, or thalamus are most often associated with acquired hemidystonia likely due to disruption of striatal-thalamic interconnections. ${ }^{2}$ Acquired dystonias, including poststroke dystonia, are relatively refractory to medical treatment, although botulinum toxin injections may be effective.

Bryan K. Ho, MD; John C. Morgan, MD, PhD; and Kapil D. Sethi, MD, FRCP (UK), Augusta, GA

Disclosure: The authors report no conflicts of interest.

Address correspondence and reprint requests to Dr. John C. Morgan, Medical College of Georgia, 1429 Harper Street, HF-1121A, Augusta, GA 30912; jmorgan@mcg.edu

\section{REFERENCES}

1. Alarcon F, Zijlmans JC, Duenas G, Cevallos N. Post-stroke movement disorders: report of 56 patients. J Neurol Neurosurg Psychiatry 2004;75:1568-1574.

2. Marsden CD, Obeso JA, Zarranz JJ, Lang AE. The anatomical basis of symptomatic hemidystonia. Brain 1985;108:463-483. 


\title{
Neurology
}

\author{
"Starfish" hand \\ Bryan K. Ho, John C. Morgan and Kapil D. Sethi \\ Neurology 2007;69;115 \\ DOI 10.1212/01.wnl.0000267410.94742.d4
}

This information is current as of July 2, 2007

\section{Updated Information \& Services}

References

Permissions \& Licensing

Reprints including high resolution figures, can be found at: http://n.neurology.org/content/69/1/115.full

This article cites 2 articles, 1 of which you can access for free at: http://n.neurology.org/content/69/1/115.full\#ref-list-1

Information about reproducing this article in parts (figures,tables) or in its entirety can be found online at:

http://www.neurology.org/about/about_the_journal\#permissions

Information about ordering reprints can be found online: http://n.neurology.org/subscribers/advertise

Neurology ${ }^{\circledR}$ is the official journal of the American Academy of Neurology. Published continuously since 1951, it is now a weekly with 48 issues per year. Copyright . All rights reserved. Print ISSN: 0028-3878. Online ISSN: 1526-632X.

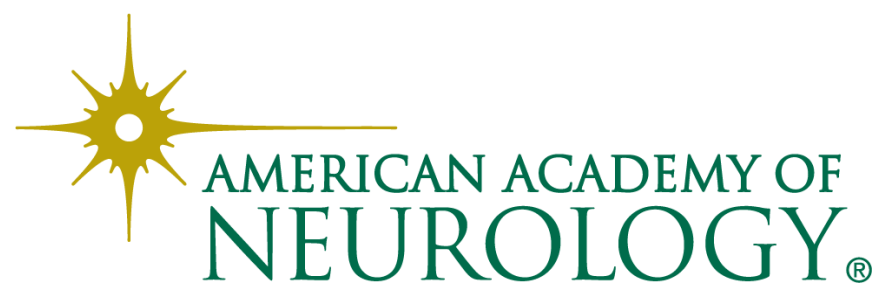

